\title{
Street-Level Bureaucracy: Bureaucratic Reform Strategies Initiated From Bottom Level
}

\author{
Novia Kencana \\ Indo Global Mandiri University \\ Palembang, Indonesia \\ Email: kencananovia@uigm.ac.id
}

\begin{abstract}
This literature review paper discusses Street Level Bureaucracy and the right effort to reform the lower level bureaucracy in order to create efficient, effective and accountable governance. Street Level Bureaucracy is a government agency that deals directly with the public in providing public services. Street Level Bureaucracy also has a role as a mediator between community and policy makers. Based on the literatures, it is found that discursive discrepancies, service delays and street levelcorruption are the main issues of the lower level bureaucrats. Those issues are caused by various factors such as an incompetent implementing agency, poor organizational culture and weak supervision. Several problem solutions offered in this study i.e. improvements from the perspective of organizational capacity, implementing agencies and socio-cultural environment conditions.
\end{abstract}

Keywords-Bureaucratic Reform and Street Level Bureaucracy

\section{INTRODUCTION}

The writings of this discuss on Street level Bureaucracy as well as the right's efforts to reform the bureaucratic level down in order to realize the Government that efficient, effective and accountable. In the activity of the bureaucracy to serve the community, Street Level Bureaucracy is the most important part to represent how quality of service bureaucrat to the public as a whole. Good about the quality of human resources as well as the deciding factor of the success of an implementation of the policy itself. Urogenital the bureaucracy level below more rampant, with the era of the autonomous region today. So that the quality of the lower levels of the bureaucracy became a major task for the sustainability of the bureaucracy that existed in Indonesia.

Lipsky revealed that street level bureaucracy has vital role running a policy that has been created. Even with regard to its functions, the bureaucratic level below holds full control in delivering program information or policies directly to the public. (Lipsky in Anthony,2012) This concept suggests that sometimes the mindset that society considers that the lower levels of the bureaucracy that was incorrect. Thus, the lower level bureaucracy this was the key to success is a policy, a program or a service that is formulated at the central level it can succeed or not.
More urgent again, lower-level officials increasingly have a function that is not less important compared to the bureaucratic top level due to various reasons. First, the lower level of the apparatus the apparatus is directly related to the community or target group so that they are often faced with the uncertain situation as well as a fairly high complexity. Second, they play a role in doing the interpretation directly to the public over the policy objectives in the field. Third, the complexity of managing traffic information as well as a mediator between the community to policy makers and vice versa. Fourth, the roles in doing coordination so that relations between the institutions involved in the implementation can be managed properly. (Lipsky dkk in Purwanto, 2012:166)

However, the performance of the resulting from this front guard bureaucrat has not shown satisfactory results for the people of Indonesia. This can be demonstrated through the large number of reports or public complaints to the Ombudsman of the Republic of Indonesia over alleged maladministration. The alleged mal-Administration of the community complained of is the alleged delay go on top of the service obligations should they give to the community as much as $25.89 \%$, digression Procedure as much as $20.33 \%$, and for not providing services as much as $16.60 \%$. Report Data or public complaints based on alleged mal-administration can be seen from graph 1 below: 
Graph 1. Reports/Public Complaints Based On Alleged MalAdministration

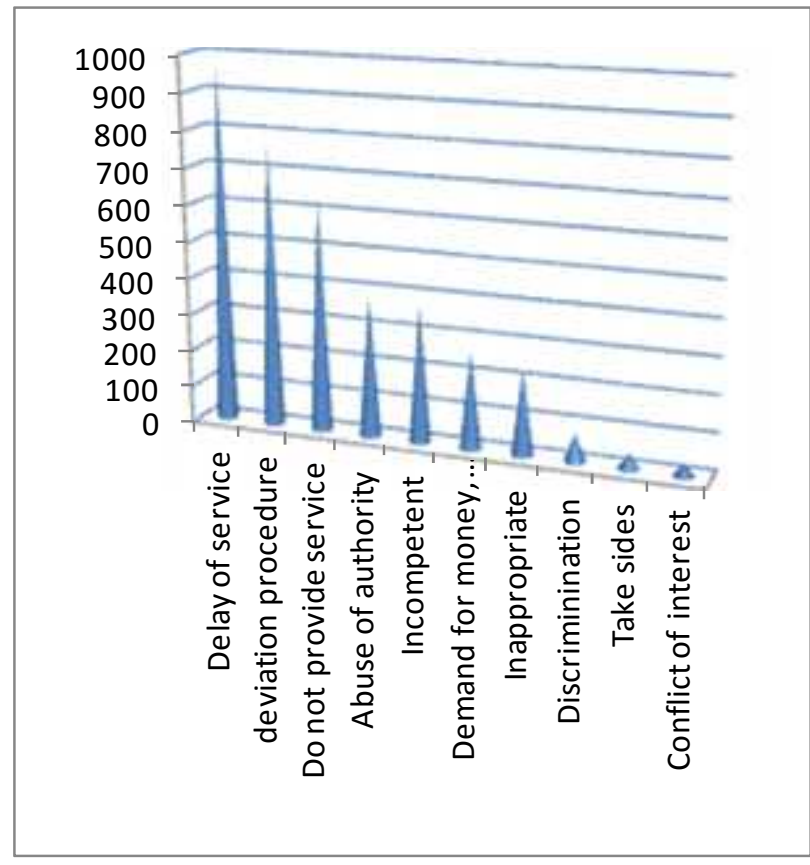

Source: Quarterly Report I, Ombudsman of the Republic of Indonesia, 2015

While the data are obtained from the quarterly report of the Ombudsman of the Republic of Indonesia Year I 2015 shows that establishments that occupy the largest order of alleged mal-administration complained by the community, namely local government district/city. This shows that the performance of the bureaucracy at the lower level in this case local government district/city that correlate directly with communities still considered less, which then impact to the quality of service provided to the community.

In addition the report data from The Global Competitiveness Report 2016-2017 indicate that the Inefficiency of government bureaucracies become biggest issue number two after corruption. Although this data is used for analysis of International economic forum. However, at least the data can become a benchmark at the same time warning for Indonesia, that indeed the performance of the bureaucracy of Government we are in zones that are not secure. The following is a table 1 regarding the factors affecting economic effectiveness in Indonesia:

Table 1. Most Problematic Factors for doing Business

\begin{tabular}{|l|c|c|}
\hline \multicolumn{1}{|c|}{$\begin{array}{c}\text { Global Competitiveness } \\
\text { Index }\end{array}$} & Rank/138 & Score (1-7) \\
\hline Institutions & 56 & 4.1 \\
\hline Infrastructure & 60 & 4.2 \\
\hline $\begin{array}{l}\text { Macroeconomic } \\
\text { environenment }\end{array}$ & 30 & 5.5 \\
\hline Helath and primary education & 100 & 5.3 \\
\hline Higher education and training & 63 & 4.5 \\
\hline
\end{tabular}

7 DEOHपCont.

\begin{tabular}{|l|c|c|}
\hline Goods market efficiency & 58 & 4.4 \\
\hline Labor market efficiency & 108 & 3.8 \\
\hline Financial market development & 42 & 4.3 \\
\hline Technological readniness & 91 & 3.5 \\
\hline Market Size & 10 & 5.7 \\
\hline Business sophistication & 39 & 4.3 \\
\hline Innovation & 31 & 4.0 \\
\hline
\end{tabular}

Source: The Global Competitiveness Report, Year 2016-2017

Various data above has shown that the effectiveness of the bureaucracy that exists in Indonesia, including street-level bureaucracy in it still has numerous problems and challenges. So the much-needed reform of the bureaucracy in particular for street level bureaucracy that is efficient, effective dan accountable. This paper is intended to give description of theoretical about the street level bureaucracy and bureaucratic reform strategies to achieve it.

\section{RESEARCH METHODS}

This paper using the method of the study of literature. So the majority of the data used are secondary data in the form of bureaucratic performance reports, legislation, journals, ejournals, as well as books related to the reform of the bureaucracy and street-level bureaucracy. The secondary data is reduced, in the analysis, conclusions drawn and verified.

\section{DISCUSSION}

\section{A. The Concept Of The Reform Of Bureaucracy}

Khan (1981) reveal that the reform effort is understood as a change in the subject matter in a bureaucratic system that aims at changing the structure, behavior and the presence or habitude long. Whereas Quah (1976) defined reform as a process to change the process, bureaucratic procedures and public attitudes as well as behavior of bureaucrats to achieve effectiveness of bureaucracy and national development goals. Next Effendi (2010) revealed that effort Setup development bureaucracy in comprehensive referred to as bureaucratic reform. Construction of bureaucracy in a comprehensive manner in this case in the form of $\mathrm{p}$ development is clean and free of bureaucratic $\mathrm{CCN}$ andregarding the whole joint of bureaucracy, not just CIVIL SERVANTS/bureaucrats, however, includes the construction of structures, systems, business process, and character/moral ethics . (in Raska, 2012)

Of the various opinions of the experts, in essence a bureaucratic reform is an effort for the Government to change the order of the institutional and human resources in it to be able to become an institution and a better bureaucrat again. It is said that the ideal bureaucracy or an already good if the level of trust the community against the bureaucracy increases, the minimum practices of corruption, collusion and nepotism, the quality of public service is good, the level of efficiency, 
effectiveness and optimal productivity, the existence of transparent and accountability, as well as the work ethic and discipline of the bureaucrats. (Accessed via: http://u.lipi.go.id/1351657451)

While in the presidential Regulation No. 81 the year 2010 about the Grand Design of the reform of the bureaucracy, bureaucratic reform 2010-2025 is meant as a major shift in paradigm and Indonesia governance. The changes contained in the the purpose such as: first, reduce and eventually eliminate any misuse of authority by public officials in the agencies concerned. Second, the country that has the mostimproved bureaucracy. Third, improving the quality of service to the community. Fourth, improving the quality of the formulation and implementation of policy/program

agencies. Fifth, improve efficiency (cost and time) in the execution of all Facets of the Organization's task. Sixth, making bureaucratic Indonesia anticipatory, proactive, and effective in the face of globalization and the dynamics of environmental change.

To measure the success of the reform of the bureaucracy in Indonesia, In the regulations of the Republic of Indonesia Number 81 Presidential Year 2010 about the Grand Design of the reform of the bureaucracy 2010-2025 there are some major performance indicators measured (key performance indicators), namely: first, the realization of a Government that is clean and free of corruption, collusion, and nepotism. Secondly, the attainment of improved quality of public services to the community. Third, increasing the capacity and accountability of the performance of the bureaucracy.

While there are some indicators that are commonly used in measuring the performance of public bureaucracy, namely: (1) Productivity, i.e., indicators to measure the level of efficiency and effectiveness of the service. (2) Quality of service, i.e., indicators to measure the quality of service. It can be seen from the level of community satisfaction towards the services provided, other indicators is the ease of information, the simplicity of the procedure and the costs that are relatively affordable. (3) Responsiveness, i.e. indicators to identify community needs, drawing up the agenda and the priorities of the Ministry. Responsiveness is described as a form of alignment between the program and service activities with the needs and aspirations of the community. (4) the Responsibilities, i.e. the implementation of the Organization's activities to explain whether the public was done in accordance with the principles of administrative right or in accordance with the principles of correct administrative or organizational policy, compliance with good explicit or implicit. (5) The accountability, that refers to how large public organizations and activities policies subject to political officials elected by the people (Dwiyanto, 1995). (6) Efficiency, i.e. concerning the consideration of success public service organizations get a profit, gaining production factors and considerations that come from economic rationality. (7) effectiveness, namely with regard to whether the purpose of the Organization the public service reached related to technical rationality, values, mission, goals, organization and functions of the agent of development. (8) The justice, namely the question of how the distribution of the service is done the apparatus to all of society. (9) Intended responsiveness as a criteria to measure how the response apparatus in providing service to the community. (Kumorotomo, 1996)

\section{B. Bureaucratic Reform strategies from Bottom Level}

Bureaucratic reform strategies is a way for the Government to undertake the fundamental changes of the weaknesses of the bureaucracy, like a bad service, the quality of human resources is not yet optimal, deviation procedures, abuse of authority to cases of bribery, collusion and nepotism (see chart 1). This section would like to bureaucratic reform strategies initiated from the bottom level. From various references which are obtained, then this article offers strategies of reform of the bureaucracy from three perspectives. First, Institutional Capacity Development Perspective. Second, The perspective of Implementing Agents and a third, the perspective of the social and Cultural Environment. Following this rather simplistic explanation of these three perspectives.

\section{B.1 Perspective Of Institutional Capacity}

Riggs (1985) revealed that institutional development is a pattern that shows an increase in the effectiveness of the utilization of the resources available to achieve the objectives that have been set. While according to Israel (1990) refers to the process of institutional development to improve capacity in human resource deployment and streamline financial. Further Sumpeno (2002) explains that the expected results with the strengthening of this capacity is first, the strengthening of individuals, organizations and communities. Secondly, the formation of capacity and model programs. Third, the formation of institutional actors and synergists. (in the Kencana, 2013).

The perspective of this Organization's capacity is defined as the view for the Government to improve the quality, structure, systems and institutional from the bureaucracy-level bureaucracy. Of the various references to the concept of the reform of the bureaucracy, reform itself is the goal of realizing the institutional capacity of the organization or are able to support the efficiency and effectiveness of the lower-level authorities in the performance of the service.

There are three dimensions of the strategy has to offer, namely restructuring, revitalizing and Refungsionalisasi (Sobandi in the Kencana, 2013:30) described as follows:

1) Restructuring actions, namely to change the organizational structure that was considered was not in accordance with the needs of the Department/Agency area.

2) Revitalization, is awarding the energy or resources to the lower levels of the bureaucracy in order to optimize its performance. Such as: an increase in the budget allocation under the bureaucracy level, the addition of the authority for the lower level bureaucrats, the addition of the 
supporting facilities and infrastructure facilities, strengthen ethical governance

3) Refungsionalisasi is an action or efforts to enable something that previously did not work, for example: to reaffirm the rights and authority of lower-level bureaucrats, optimize function regulations for strengthening capacity institutional.

\section{B.2. The Implementing Agency Perspective}

The implementing agency is the dimensional perspective that cannot be released to a bureaucratic institution or progress. In some ways, the dexterity promptness, loyalty, and ability of bureaucrats in serving the community becomes a factor that greatly influences the effectiveness of an institution. However, to lower-level bureaucrats in terms of level of education and understanding of the duties as public servants are still in the category of less. For clearer Protass (1979) cited by Kim (2010:17) revealed that there were three type bureaucrats front guard relating to the submission of the information policy, namely: (1) Suppress Information Bureaucrats. This type of bureaucrats are those who deliberately hide some information which should be conveyed to the public. Such as: free service service, procedures, access services, and service assurance. Types of bureaucrats is very detrimental to society and gives a bad image to the institution

or the Office. (2) Provide Inadequate Information Bureaucrats. This is a bureaucrat bureaucrat type provides information but not complete so that communities lacking the complete understanding of the purpose and benefits of programs or policies that have been made. (3) Provide Supportive Information Bureaucrats. This is a type of bureaucrat type is most ideal. These bureaucrats give information adequately, accurate, and fair to the community so that misunderstandings do not occur the procedures and administrative irregularities. Type this is a bureaucrat bureaucrat gave outstanding contributions to public service. (Kim Anthony, in 2012:172)

From the results of a quarterly report the Ombudsman of the Republic of Indonesia I Year 2015 (see p. 2) shows that in Indonesia there are still many bureaucrats who belongs to

type bureaucracts suppress information and provide inadequate information bureaucrats. There are several factors that affect the behavior, such as: low income levels, educational levels are inadequate, as well as pressure-pressure that requires such information covering bureaucrats and not providing service maximum. (Anthony, 2012)

Then it needs to be able to Maximized bureaucrat type Provide Supportive Information Bureaucrats are:

1) Improve the recruitment pattern of lower-level bureaucrats as well as reduce the practice of honorary degrees on lower level institutions. Honorary practice when not managed properly even precisely deliver the results not as good as honorary utilize of CIVIL SERVANTS for the task anyway, otherwise inexperienced honorary thus provide imagery and the performance is bad for the community.

2) Improve education and understanding bureaucrat-related task such as: providing training for personal development, leadership training, training on governance, training of public service to the entire lower level bureaucratic apparatus.

3) Improve management of apparatus in a manner providing clarity and certainty of career for street level bureaucracy (Thoha, 2008)

4) Improve Welfare bureaucrats with a system of rewards or bonuses for professional bureaucrats.

5) To improve the understanding of lower-level bureaucrats to take advantage of "discretion" as a tool to bring about a Government that is effective, efficient and accountable. Discretion in this regard is an act committed outside of procedures or SOP but instead aims to provide efficient and effective service as well as minimize the problems and failures of the program.

\section{B.3. The perspective of the social and Cultural Environment}

Bureaucratic culture of the present Indonesia is inseparable from the cultural influence of paternalistic and feudalism which has been embedded since the time of the Kingdom. There are characteristics of the Kingdom's bureaucracy still felt to this day, includes: (1) the sovereign consider and use as private affairs of public administration (2) the administration of the household is an extension of the Palace (3) service is intended to the King's private (4) Salary from the King to the servants of the Kingdom on the fact of the matter is the saving that can be withdrawn at any time upon the will of the King (5) Royal officials could act against the people's whim, as performed by the King . (Suwarno in Kurniawan, 2013).

The supposition that the officials is a high position who are able to determine all matters and subjects is a subordinate who does not become a special attention, is the root of the culture is still entrenched until now and should be in off soon. The attitude has finally come into effect against bad bureaucratic Indonesia, and one of the bad culture that still continue to be rooted in bureaucratic Indonesia, both the central level as well as street level bureaucracy is corruption. Many bureaucrats consider that tenure, infrastructure and facilities provided by the State is privately owned. As for the bureaucrats that are on the lower level, which did not get the best facilities eventually made the information and service provided to the public is a service that must be paid by the community. So case jungle, bribes, kickbacks and money to bureaucrats so much going on. Whereas according to Thoha (in Yusrialis, 1993) a bureaucratic culture indeed emphasized that perpetrators of the bureaucratic apparatus in carrying out his duties with separate ownership thanks over public facilities and facility. Differentiated between private property and public property (see Raden 1998:13). Therefore, there are some strategies that are offered to minimize the bad culture, such as: 
1) Change the mindset of the bureaucrats that they are public servants who have a duty to give the rights of the community in accordance with the regulations.

2) Changing the culture of bureaucratic corruption, slow and impressed not qualified to become a bureaucratic culture that is responsive, creative, and accountable, disciplined and have a high work ethic

3) Strengthen the legal system, with Indonesia still uphold the noble values that have been instilled in the society of Indonesia.

4) Strengthen the supervision on the lower levels of the bureaucracy and reaffirms the sanctions or penalties that accrue when there are apparatus that performs an aberration. For example merevitalisasi the Agency of the Republic of Indonesia and the Ombudsman Ombudsman area as the Agency's oversight of public service Indonesia.

\section{CONCLUSION}

Study on the reform of the street level bureaucracy in Indonesia it is a concept to see what problems that often occur in the lower levels of the bureaucracy. This paper attempts to provide a strategy for reforming the bureaucracy from the bottom level. Bureaucratic reform strategies is a way for the Government to undertake the fundamental changes of the weakness of the bureaucracy, like a bad service, the quality of human resources is not yet optimal, deviation procedures, abuse of authority to cases of bribery, collusion and nepotism. From various references which are obtained, then this article offers strategies of reform of the bureaucracy from three perspectives. First, Institutional Capacity Development Perspective. The perspective of institutional capacity is defined as the view for the Government to improve the quality, structure, systems and institutional from the bureaucracy-level bureaucracy down through the dimensions of restructuring, revitalizing and refungsionalisasi. Second, the Perspective of Implementing Agents. This perspective gives a view to be able to change the pattern of recruitment officers, improvement of educational apparatus, certainty of granting career and as well as the utilization of discretion as a tool to realize an effective, efficient bureaucracy and accountable. And third, the perspective of the social and Cultural Environment. This perspective offers to the bureaucrats to fight Indonesia's cultural heritage a bad bureaucracy that is by way of strengthening the legal system in Indonesia, strengthen the supervision on the lower levels of the bureaucracy and reaffirms the sanctions or penalties obtained if the authorities conduct a diversion.

\section{REFERENCE}

[1] Dwiyanto, Agus, Reformasi Birokrasi, Kepemimpinan dan Pelayanan Publik: Kajian Tentang Pelaksanaan Otonomi Daerah di Indonesia. Yogyakarta: Gava Media, 2009.

[2] Dwiyanto, Agus, Reformasi Birokrasi Publik di Indonesia. Yogyakarta: Gadjah Mada University Press, 2012.
[3] Kencana, Novia, Dinamika Kelembagaan (Suatu Kajian Tentang Penggabungan Lembaga Ombudsman Daerah DIY dan Lembaga Ombudsman Swasta DIY). Tesis: Universitas Gadjah Mada, 2013.

[4] Kurniawan, Robi Cahyadi, Reformasi Pelayanan Birokrasi.Diakses pada: jurnal.fh.unila.ac.id/index.php/fiat/article/download/794/68, 2013

[5] Lipsky, Michael, Street Level Bureucracy: Dillemmas of The Individual in Public Service. New York. Rusell Sage, 1980.

[6] Purwanto, Erwan Agus., Sulistyastuti, Dyah Ratih, Implementasi Kebijakan Publik: Konsep dan Aplikasinya di Indonesia. Yogyakarta: Gava Media, 2012.

[7] Thoha, Miftah. Birokrasi Pemerintah Indonesia di Era Reformasi. Jakarta: Kencana, 2014.

[8] Peraturan Presiden No 81 Tahun 2010 Tentang Grand Design Reformasi Birokrasi 2010-2025.

[9] Yusrialis, Budaya Birokrasi Pemerintahan : Keprihatinan dan Harapan. Jurnal Sosial Budaya Vol. 9 No.1. Januari-Juli 2012.

[10] Raska, Prita, Efektivitas Reformasi Birokrasi di Sekretariat Presiden Kementerian Sekretariat Negara RI dalam Pencapaian Program Penguatan Akuntabilitas Kinerja. Skripsi : Universitas Indonesia, 2012. 